HStud 24 (2010)2, 215-224 DOI: 10.1556/HStud.24.2010.2.4

\title{
A COFFEEHOUSE ON THE LINGUISTIC FRONTIER
}

\author{
ROBERT NEMES \\ Colgate University, Hamilton, NY \\ USA
}

\begin{abstract}
A century ago, Bihar/Bihor County was a rather unremarkable corner of the Hungarian Kingdom, one situated far from international boundaries. The population of Bihar/Bihor was almost equally split between ethnic Hungarians and ethnic Romanians, a fact of little consequence until the last decades of the nineteenth century, when a number of middle-class national activists began to emphasize the region's status as a national borderland and worked to define and defend the Hungarian-Romanian border they saw running through it. This essay explores the nationalists' efforts through a local cultural association, A Biharvármegyei Népnevelési Egyesület (Bihar County Society for Popular Education). Its aim is to show that the sharp lines that appeared on maps of "the nationalities of Austria-Hungary" emerged in a particular historical context, and also that these lines were much more blurry than many mapmakers and historians would have us believe.
\end{abstract}

Keywords: associations, nationalism, linguistic frontiers, borderlands, Bihar county, Transylvania, Partium

This project started with a coffeehouse. The EMKE coffeehouse opened in 1902 in Nagyvárad/Oradea, a provincial town in what was then Austria-Hungary, but is today Romania. From the start, the EMKE coffeehouse was celebrated for its luxurious Secessionist interior, excellent wait staff, four large billiard tables, and wide selection of foreign and domestic newspapers (Péter, 2002, 94). Most scholars today know the EMKE for its connection with Endre Ady, then working as a journalist in Nagyvárad/Oradea and soon to become Hungary's foremost modernist poet. Sitting on the EMKE's terrace, Ady wrote some of his earliest poems, as well as theater reviews, sharp-tongued editorials, and postcards to a married woman with whom he had fallen desperately in love. Ady was not alone at EMKE: the mayor and other notables gathered there in the afternoon to smoke pipes, drink coffee, and decide town affairs; the local literati also had their own table, where they were joined by doctors, lawyers, and teachers. The EMKE coffeehouse, in short, fulfilled all the functions of a classic coffeehouse: it offered strong coffee, well-lit tables, and assorted newspapers to a diverse public, and in 
the process, it created a space for the exchange of ideas, the integration of different social groups, and the ferment of literary activity.

What originally drew me to this coffeehouse, however, was its name. "EMKE" is an acronym for Erdélyrészi Magyar Közmüvelödési Egyesület (Hungarian Cultural Association of Transylvania), which we would call a nationalist pressure group, the Hungarian equivalent of the Austrian Deutsche Schulverein or the German Alldeutscher Verband. Ostensibly dedicated to the cultural and economic development of the countryside, in reality the association was preoccupied with national self-defense and committed to the propagation of the Hungarian language among the polyglot population of the Kingdom of Hungary (the first language of roughly half of the total population was something other than Hungarian). To publicize its cause and fund its efforts, EMKE licensed its name to a handful of coffeehouses across Hungary, including the one in Nagyvárad/Oradea (Figure 1). In return for use of the name, coffeehouse owners made an annual donation to the society. Every cup of coffee drunk in an EMKE coffeehouse, it was said, meant a few pennies more for the Hungarian national cause. For real enthusiasts, there was also EMKE writing paper, EMKE soap, EMKE calendars, and of course, EMKE paprika (Sándor, 1910, 368-70). Our classic coffee house, then, turns out to have a very direct link to an intolerant form of nationalism rooted in everyday practices.

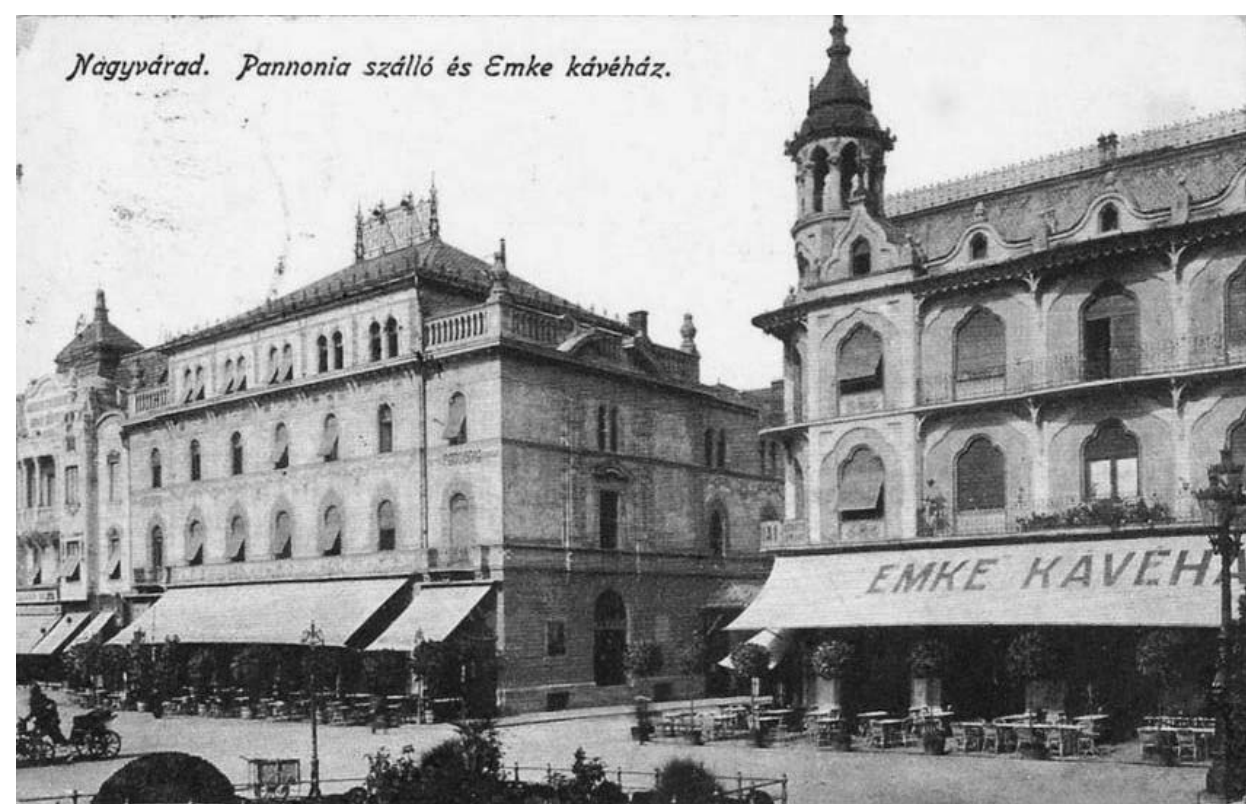

Figure 1. On the right, the EMKE coffeehouse in Nagyvárad/Oradea. c. 1910. Undated postcard 
What are we to make of this curious coffeehouse, at once liberal and illiberal, inclusive and exclusive? It is important to recall that the EMKE was only one of nearly two dozen "cultural associations" that operated in Hungary in the decades around 1900. Their names present a welter of forgotten acronyms - AMKE, DKE, DMKE, FMKE, VMKE - whose shared letters signaled the associations' common educational goals, middle-class memberships, and close relations with the Hungarian state. Both contemporaries and historians have sharply criticized these organizations. Writing in 1886, the politician Lajos Mocsáry decried their dishonest language and bullying tactics (Mocsáry, 1886). Nearly three decades later the sociologist Viktor Aradi asserted that their goals were "antediluvian and wrapped in empty slogans," and that their activities amounted to little more than empty posturing before "chauvinist elements of the public" (Aradi, 1914, 24). Historians have been equally dismissive, long describing the cultural associations as agents of the Hungarian state's campaign of Magyarization - that is, its attempts to expand the use of the Hungarian language in schools, courts, local administration, and everyday life. In recent decades, scholars have begun to look at the process of nationalization in new ways, emphasizing the importance of sociological factors such as urbanization and social mobility. They have also situated the Hungarian case alongside similar nation-building projects in Imperial Germany, Tsarist Russia, and France under the Third Republic. Even with these promising developments, however, we still know comparatively little about how nationalist politics played out at the local level.

This article looks closely at one Hungarian cultural association: A Biharvármegyei Népnevelési Egyesület (Bihar County Society for Popular Education), or BNE for short. The BNE was founded in Nagyvárad/Oradea in 1884, operated in the surrounding Bihar/Bihor County for the next two decades, and acted as a sister organization to the larger EMKE. In examining the BNE, I am less interested in exploring its connections to other cultural associations or to the Hungarian state than in situating it in its local context. In particular, I seek to illuminate the BNE's highly symbolic understanding of local geography and its assertion that a contested "national borderland" ran through Bihar/Bihor County. In this I draw upon scholarly literature that has emphasized the "social construction of boundaries," with its focus on imagined geographies and collective identities. When viewed from this perspective, cultural associations such as the BNE appear much more interesting - and less effective - than is often recognized in the existing scholarship. Their importance, I argue, lies less in their limited influence on the linguistic practices of the wider population than in what they reveal to us about the "mental maps" of national-minded elites. To develop this argument more fully, the following sections outline the many obstacles that nationalists faced on the ground, their inventiveness and tireless agitation, and the indifference and opposition they frequently encountered. 
To understand the origins and activities of nationalist organizations such as the BNE, one must understand the mindset of its most active members. The BNE's moving force and long-time secretary was an official named Orbán Sipos, who had earlier worked as a teacher, lawyer, and MP, and from 1879 onward served as a royal school inspector in Bihar/Bihor County. Like much of the Hungarian elite, Sipos was a committed political liberal and staunch Hungarian nationalist, and he saw no contradictions between these two ideologies. Thus Sipos wrote despairingly about the poverty and illiteracy he encountered the countryside and hoped that the BNE could bring progress and civilization to the region's many poor villages. But Sipos's hopes were tinged with fear, and in Bihar/Bihor County, Sipos saw a ceaseless struggle between ethnic Hungarians and ethnic Romanians, both of whom comprised roughly half the population. Sipos sometime described this contest in elemental terms, describing the encroaching "flood" of Romanians and the stranded "islands" of Hungarians in need of rescue. More commonly, however, Sipos used the language of cartography: the mission of the BNE, he wrote, was to strengthen ethnic Hungarians living on the "contiguous borders" with Romanians (Sipos, 1909, 4).

Sipos's fears of Romanians were not directed at an abstract "other." Rather, they reflected a very specific understanding of local conditions. The contours of Sipos's map of Bihar/Bihor County can be seen in the following passage:

\footnotetext{
What beauty, rarities, and treasures lie hidden in Bihar County's plains, vast lowlands, and golden fields; how valuable for the homeland is the spiritual and moral worth of the vigorous people of the plains. But dear to us also is the place, where unexplored and unexploited mountains, wilderness, and forests cast their shadows, and where the population, spiritually and materially neglected, wallows in misery before the eyes of civilization. This population does not understand or feel their higher human and purely patriotic destiny (Sipos, 1889, 3).
}

The key to unlocking this passage lies in the unspoken equation of the plains with Hungarians and the highlands with Romanians. In demographic terms, this equation had some merit, and one could in fact trace a broad linguistic frontier separating Hungarian-speakers and Romanian-speakers and meandering north-south through Bihar/Bihor County. What stands out in Sipos's account is the way it superimposes nationality, civilization, and morality onto the linguistic frontier. In this symbolic geography, the imprecise linguistic frontier becomes a clearly demarcated national borderland.

Sipos and the leaders of the BNE were not the first to discover this borderland. For decades, cartographers had produced maps of Austria-Hungary's different peoples, who were usually defined as nationalities or races, as in William 
Shepherd's influential 1911 Historical Atlas (Figure 2). Mapmakers drew upon the results of the decennial censuses conducted in both Austria and Hungary. These censuses included questions about language use and religious affiliation, which were widely understood to be key markers of national belonging. Where Sipos broke new ground was not in mapping and counting the different ethnic groups in Bihar/Bihor County, but in seeing the lines on the map as a source of national anxiety and using them as a spur to political mobilization.

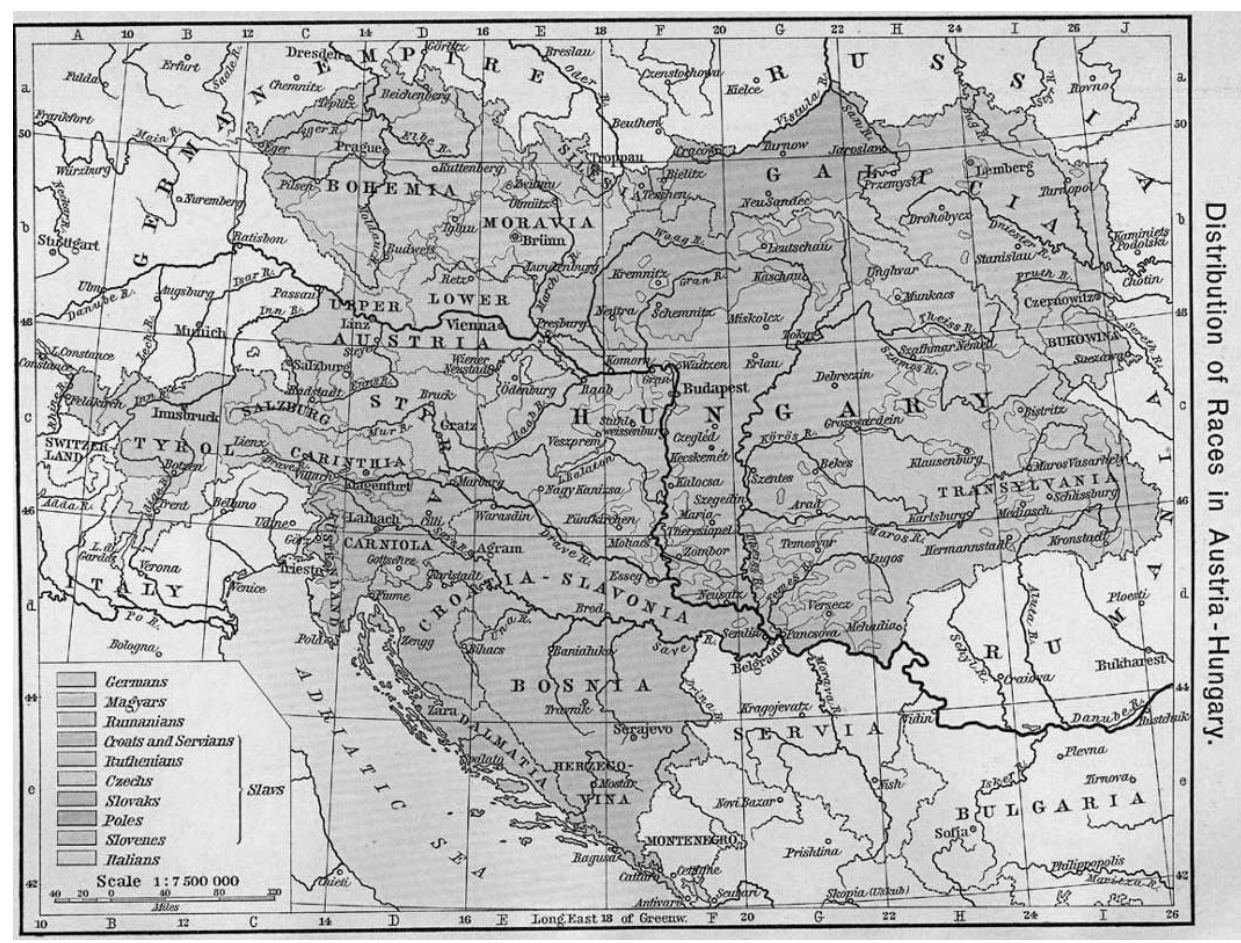

Figure 2. "Distribution of Races in Austria-Hungary." Nagyvárad/Oradea is shown here with its German name (Grosswardein) and appears just below the "A" in Hungary.

Reprinted from William R. Shepherd, Historical Atlas (New York: H. Holt, 1911), 168.

It is important to recall, however, the many obstacles that Sipos and the BNE faced in convincing their neighbors that Bihar/Bihor County contained a threatened borderland. Nationalist ideology, with its clear separation of "us" and "them," sat uneasily with the messy facts on the ground in Bihar/Bihor County. Centuries of immigration, conversions, and mixed marriages had created a state of permanent flux, especially in the towns and villages to the east of Nagyvárad/Oradea. There were, moreover, many locals who did not fit easily into a single national category, including the villagers and townsmen who spoke two languages or those who belonged to a "Romanian" religion (Greek Catholicism and 
Eastern Orthodoxy) but spoke Hungarian. The populist writer Pál Szabó has eloquently described his wife's family, which used two languages (Hungarian and Romanian) and celebrated two Christmases - the Calvinist on December 25 and the Eastern Orthodox on January 7. According to Szabó, official religions "did not live the in hearts" of the peasants of Bihar/Bihor, but "only in the state registers and in the village parsonages" (Szabó, 1973, 7). The same might be said of national categories. Sipos's national borderland, moreover, did not traverse the heavily populated plains but instead ran through thinly populated, highland regions. Writing about these remote areas, the local geographer and folklorist Sándor K. Nagy despaired that "travelers and intellectuals know less about them than they do about foreign lands" (Nagy, 1884, 3).

Even the Hungarian state proved to be a fitful ally to the BNE. Although state officials were broadly committed both to economic modernization and to linguistic Magyarization, in practice they had little interest in disturbing the status quo. This caution extended to Hungary's internal borders. A large number of internal administrative boundaries crisscrossed Hungary, dividing it into, among other things, separate confessional, electoral, military, customs, and forestry districts. The building block of these regions was the Hungarian county (vármegye). Balancing the needs of rationalization with the claims of Hungarian nationalism, the government had redrawn a number of county lines in 1876, leaving Hungary with 71 counties (including Croatia-Slavonia, 63 without it). But the state would not go further, and it had little incentive to lend legitimacy to Sipos's national borderland. And even if it had, the state could devote only limited resources to the remote regions that so worried Sipos.

These obstacles help explain the founding of cultural associations like the BNE. In the absence of decisive state action, local activists turned toward the institutions of civil society. Nineteenth-century liberals were used to working through voluntary associations and newspapers; only the BNE's goals set it apart from dozens of other associations in Bihar/Bihor County (the one it most closely resembled was ASTRA, the leading Romanian cultural association in prewar Transylvania, which had four branches in Bihar/Bihor County). The BNE's stated mission, to offer financial and pedagogical support to kindergartens, poor students, and underpaid teachers across the county, was largely a smokescreen. Its main goal was to promote the use of the Hungarian language among Romanian villagers and to rescue "de-nationalized" Hungarians. To this end, the BNE agitated for Hungarian-language kindergartens in Romanian villages and rewarded village teachers whose instruction spread "the spirit of Hungarian patriotism." The BNE also published a weekly newspaper, which bore the title Népnevelési Közlöny (The Popular Education Gazette) and was aimed not at the lower classes (the targets of the BNE's educational initiatives) but at the higher social classes 
that comprised the membership of the BNE: urban professionals, gentry landowners, and a large number of village schoolteachers and clergymen.

The BNE proved to be both inventive and resourceful in taking its campaign into the villages of Bihar/Bihor County. In addition to the educational initiatives already mentioned (kindergartens, prizes, and stipends for teachers), the BNE sponsored essay contests, held fund-raising balls, and encouraged the observance of important national holidays (with March 15 first among them). To instruct locals about their immediate surrounding, the BNE also helped Sándor K. Nagy publish his three-volume travel guide to Bihar/Bihor County and distributed a large wall map of the county to local schools. Crucially, the map used only Hungarian names (and not Romanian or German ones) for settlements and topographical features. Sipos attached great importance to names, which he saw as an outward indication of national belonging. Sipos thus declared in the BNE's newspaper that "the Magyarization of family names is unimpeachable evidence that one will venture to shoulder openly and determinedly the requirements of belonging to the Hungarian state" (Népnevelési Közlöny, June 1897, 69). By this logic, people and communities with non-Hungarian-sounding names were either ignorant of the duties of citizenship or potentially disloyal.

Two patterns stand out in this whirlwind of activity. First, in taking its campaign into the villages, the BNE attempted to attach political meanings to features of everyday life (places names, kindergartens, and travel) that many locals had not previously defined in political terms. In prewar Hungary, the strict limits on formal political life (around six per cent of the population had the vote) often had the curious effect of allowing "politics" to shape a wide range of institutions, spaces, and behaviors (Nemes, 2005, 186). This is related to the second point, the highly symbolic and highly performative nature of the BNE's activities. This point was not lost on the BNE's opponents. In denouncing local Romanians in Bihar/Bihor County who supported the BNE, a Romanian-language newspaper singled out those teachers whose Romanian students greeted one another in Hungarian in the street (Tribuna, April 1/13, 1887, 1). Nationalists on both sides took seriously the premise of the EMKE coffeehouse: namely, that one could demonstrate one's national belonging not just in grand gestures (for example, by changing one's name), but in smaller, more prosaic acts (by drinking a cup of coffee, greeting someone in the street).

But how much success did the BNE really have? There are many indications that the BNE failed to mobilize the population of Bihar/Bihor County. Its membership, which surpassed 1,750 within a year of its founding, fell by nearly 50 per cent in the following decade. Because many remaining members neglected to pay their dues, the BNE had to cut back on its activities even further. By the late 1890 s, the BNE had lost momentum, leading one of its members to write bitterly 
that the BNE "had always scraped along under unfavorable circumstances, obtaining only negligible support from the wider public and barely counting enough members to secure its existence" (Népnevelési Közlöny, May 15, 1898, 9-11). The BNE survived into the twentieth century, but in a different form: the bulk of its membership (and teachers in particular) wanted to focus more on pedagogical and professional issues than on the loud but often ineffective national agitation of its early years.

Why did things not go as planned for the BNE? Sipos laid much of the blame at the feet of the Romanian nationalist press, which, he claimed, had relentlessly attacked the BNE and poisoned relations between Hungarians and Romanians in Bihar/Bihor. But Sipos also acknowledged that the indifference of many Hungarians had also undermined the BNE. This indifference encompassed both urban dwellers as well as the residents of the highlands. An anecdote reported by Sipos sheds light on the latter's behavior, and it is worth quoting in full:

\begin{abstract}
We were waiting for a long time for horses in the mayor's office of a mixed-language village in the Tenke district. The Hungarians here are still a majority. As we waited, an impressive looking man entered, greeted in Romanian the Hungarian-born mayor, who returned the greeting and began their discussion - in the Romanian language. Presently understanding that the man there on business was also a Hungarian, we interrupted the conversation with a gentle reproach, to which the man replied, "Why shouldn't I speak Romanian, when I know it just as well as Hungarian?" The mayor in turn offered as an excuse that he had orders that are different from our principles. This justification certainly did not correspond with the truth, but the mayor still lives and serves today, and if he deems to read these lines, he will recognize himself (Sipos, 1903, 79).
\end{abstract}

Most obviously, Sipos's account shows the refusal of locals to attach wider meanings to everyday language use. It also shows Sipos as a man of national principles, willing to intervene in other people's affairs and to shame them when necessary. At the same time, the episode reveals strategies employed by local elites in the face of Sipos' nationalism: the first man's pragmatic defense of bilingualism, and the mayor's more shrewd reference to unspecified "orders" that seemingly forced him to speak Romanian. In this small drama we can see what the anthropologist James Scott has called the "arts of resistance," in which ordinary people use ignorance, disguise, and other strategies to subvert the arguments of outside authorities (Scott, 1990).

Let me conclude with two points about the wider meanings of the BNE's attempt to create "national borderlands." First, it mattered. Writing about similar events in the Austrian half of the Monarchy, Pieter Judson concluded that "nationalists succeeded brilliantly in nationalizing perceptions of the rural language fron- 
tier by 1914," even as they "largely failed to nationalize its populations" (Judson, $2006,5)$. Over the long term, nationalists popularized a set of images in which the Hungarian-Romanian linguistic frontier appeared as a site of anxiety, conflict, uncertainty, and loss. Such images would prove enduring, and they took on new meanings when a state border was drawn through Bihar/Bihor County in 1919. In the space of just a few decades, nationalists in Bihar/Bihor, as well as in other regions of the Hungarian Kingdom, succeeded in superimposing national borderlands onto the historic borders of Hungary. Many locals may not have taken notice, but officials, scholars, and mapmakers did.

But the local indifference described here also mattered. To be sure, the townsmen who ignored the BNE and the villagers who used customary names and a mix of languages did not openly challenge the dominant political and socioeconomic structures of prewar Hungary. Yet their everyday practices held the potential to redefine what it meant to call Bihar/Bihor a borderland, in which the region is defined not by conflict and tension, but by cultural contact and mutual recognition. In this telling, Bihar/Bihor is a bridge, not a battle zone. Some residents of Bihar/Bihor County embraced this alternate meaning of the borderland at key moments during the twentieth century, and the bridge metaphor has gained new currency again today with the establishment of several Euroregions across Bihar/Bihor. Although regional cooperation has a poor track record in Eastern Europe, the larger point here is the continued existence of multiple, competing symbolic geographies, even in unexceptional places like Bihar/Bihor.

This brings us back to the EMKE coffeehouse. The peace treaties following World War I gave Nagyvárad/Oradea to Romania. Although the Romanian rulers were eager to demonstrate the Romanian national character of their new city, they also wanted to demonstrate their connections to the wider world. It was in this spirit, perhaps, that the name of the EMKE coffeehouse was eventually changed to the Hotel Astoria. Some hard-core Romanian nationalists may have heard echoes of "ASTRA" in the new name, but more worldly visitors would have known that "Astoria" had been borrowed from the famous hotel of the same name in New York City. Once again, nationalism did not tell the entire story.

\section{Bibliography}

Aradi, Viktor (1914) 'Kulturegyesületeink kulturmunkája', Huszadik Század, Vol. 30, No. 2, 23-41.

Judson, Pieter (2006) Guardians of the Nation: Activists on the Language Frontiers of Imperial Austria (Cambridge, MA: Harvard University Press).

[Mocsáry, Lajos] X. Y., 1886. A közmüvelödési egyletek és a nemzetiségi kérdés (Budapest: Singer and Wolfner).

Nagy, Sándor K. (1884) Bihar-ország. Uti-rajzok. Vol. 1. Nagyvárad: Hollósy Jenő. 
Nemes, Robert (2005) The Once and Future Budapest (DeKalb: Northern Illinois University Press). Péter, Zoltán I. (2002) Mesélö képeslapok. Nagyvárad 1885-1915 (Budapest: Noran).

Sándor, József, 1910. Az E.M.K.E. megalapitása és negyedszázados müködése, 1885-1910 (Kolozsvár: Az E.M.K.E. Kiadása).

Scott, James C. Domination and the Arts of Resistance: Hidden Transcripts. New Haven: Yale University Press.

Sipos, Orbán (1889) 'Bevezetés’, in Márton Hegyesi Belényes és vidéke. A Bihari Kárpátegyesület 1889 évi julius hó 27-iki kirándulásának alkalmából (Nagyvárad: Hügel Ottó).

Sipos, Orbán (1903) Biharvármegye a népesedési, vallási, nemzetiségi közoktatási statisztika szempontjából (Nagyvárad: Szent László).

Sipos, Orbán (1909) A Biharvármegyei Népnevelési Egyesület története. Huszonöt éves fennállása megünneplésének alkalmára (Nagyvárad: A Biharvármegyei Népnevelési Egyesület).

Szabó, Pál (1973) Nyugtalan élet (Budapest: Szépirodalmi Könyvkiadó) Vol. 3. 